\title{
Massilia tieshanensis sp. nov., isolated from mining soil
}

\author{
Yan Du, Xiang Yu and Gejiao Wang
}

Correspondence

Gejiao Wang

gejiaow@yahoo.com.cn or

gejiao@mail.hzau.edu.cn
State Key Laboratory of Agricultural Microbiology, College of Life Science and Technology, Huazhong Agricultural University, Wuhan, Hubei 430070, PR China

\begin{abstract}
A bacterial isolate, designated strain $\mathrm{TS}^{\top}{ }^{\top}$, was isolated from soil collected from a metal mine in Tieshan District, Daye City, Hubei Province, in central China. Cells of this strain were Gramnegative, motile and rod-shaped. The strain had ubiquinone $\mathrm{Q}-8$ as the predominant respiratory quinone, phosphatidylethanolamine, phosphatidylglycerol and diphosphatidylglycerol as the major polar lipids and summed feature $3\left(\mathrm{C}_{16: 1} \omega 7 c\right.$ and/or iso- $\left.\mathrm{C}_{15: 0} 2-\mathrm{OH}\right), \mathrm{C}_{16: 0}$ and $\mathrm{C}_{18: 1} \omega 7 c$ as the major fatty acids. The $G+C$ content was 65.9 mol\%. Phylogenetic analysis based on $16 S$ rRNA gene sequences revealed that strain $\mathrm{TS}^{\mathrm{T}}{ }^{\text {was }}$ most closely related to Massilia niastensis $5516 \mathrm{~S}-1^{\top}$ (98.5\%), Massilia consociata CCUG $58010^{\top}(97.6 \%)$, Massilia aerilata $5516 \mathrm{~S}-11^{\top}$ (97.4\%) and Massilia varians CCUG $35299^{\top}$ (97.2\%). DNA-DNA hybridization revealed low relatedness between strain $\mathrm{TS}^{\top}$ and $M$. niastensis $\mathrm{KACC} 12599^{\top}(36.5 \%)$, M. consociata CCUG $58010^{\top}(27.1 \%)$, M. aerilata KACC $12505^{\top}(22.7 \%)$ and M. varians CCUG $35299^{\top}$ (46.5\%). On the basis of phenotypic and phylogenetic characteristics, strain $\mathrm{TS}^{\top}{ }^{\top}$ belongs to the genus Massilia, but is clearly differentiated from other members of the genus. The strain represents a novel species, for which the name Massilia tieshanensis sp. nov. is proposed. The type strain is $\mathrm{TS}^{\top}\left(=\mathrm{CCTCC}^{\mathrm{AB}} 2010202^{\top}=\right.$ KACC $\left.14940^{\top}\right)$.
\end{abstract}

The genus Massilia belongs to the family Oxalobacteraceae, class Betaproteobacteria, and was described by La Scola et al. (1998) on the basis of Massilia timonae, isolated from blood of an immunocompromised patient with cerebellar lesions. Subsequently, several strains belonging to $M$. timonae have been isolated from different patients (Sintchenko et al., 2000; Lindquist et al., 2003). At the time of writing, 18 species names have been validly published in the genus Massilia: M. timonae (type species), M. dura, M. albidiflava, M. plicata, M. lutea, M. aurea, M. brevitalea, M. aerilata, $M$. niabensis, $M$. niastensis, $M$. jejuensis, $M$. consociata, M. oculi, M. alkalitolerans, $M$. varians, $M$. haematophila, $M$. suwonensis and $M$. flava. Members of the genus have been isolated from various habitats such as air, soil, water and humans with different health problems (La Scola et al., 1998; Xu et al., 2005; Zhang et al., 2006; Gallego et al., 2006; Zul et al., 2008; Weon et al., 2008, 2009, 2010; Kämpfer et al., 2008, 2011, 2012; Wang et al., 2012). M. alkalitolerans (Xu et al., 2005), $M$. varians, $M$. haematophila (Kämpfer et al., 2008) and $M$. suwonensis (Weon et al., 2010) were originally assigned to

Abbreviation: MIC, minimium inhibitory concentration.

The GenBank/EMBL/DDBJ accession number for the 16S rRNA gene sequence of strain TS3 $^{\top}$ is $\mathrm{HM}_{130516 .}$

Three supplementary figures are available with the online version of this paper. the genus Naxibacter. However, according to data reported by Kämpfer et al. (2008) and Weon et al. (2010), there are no genus-specific distinctions between Massilia and Naxibacter. Kämpfer et al. (2011) proposed to transfer all Naxibacter species to the genus Massilia. The typical characteristics of members of Massilia are aerobic metabolism, Gram-negative staining behaviour, motile, rodshaped cells, summed feature $3\left(\mathrm{C}_{16: 1} \omega 7 c\right.$ and/or iso- $\mathrm{C}_{15: 0}$ 2-OH) and $\mathrm{C}_{16: 0}$ as major fatty acids and ubiquinone Q-8 as the predominant respiratory quinone, with relatively high DNA G +C contents (62-68.9 mol\%). The major polar lipids have been determined for some species of the genus as phosphatidylethanolamine, phosphatidylglycerol and diphosphatidylglycerol (Kämpfer et al., 2011, 2012, 2008; Wang et al., 2012; Weon et al., 2010).

In a previous study, 45 arsenic-resistant bacteria were isolated from mining soil in Tieshan District $\left(30^{\circ} 12^{\prime} \mathrm{N}\right.$ $114^{\circ} 53^{\prime} \mathrm{E}$ ), Daye City, Hubei Province, central China (Cai et al., 2009). The arsenic concentration of the soil was $337.2 \mathrm{mg} \mathrm{kg}^{-1}$ (Cai et al., 2009) and the $\mathrm{pH}$ was 7.4 . Concentrations of arsenic and other heavy metals are extremely high in the water, soil and sediments of this area due to the smelting of gold, copper and iron for many years (Zhang et al., 2005). By analysis of partial 16S rRNA gene sequences (about $1300 \mathrm{bp}$ ), these bacteria were preliminarily identified as members of the genera Acinetobacter, Delftia, Arthrobacter, Microbacterium, Aeromonas, 
Acidovorax, Ensifer, Janibacter, Janthinobacterium, Klebsiella, Kocuria, Micrococcus, Shewanella and Thauera (Cai et al., 2009). One strain, previously named Janthinobacterium sp. TS3, was chosen for study because of its undefined taxonomic position.

Strain identification was performed according to the recommendations for characterization of prokaryote strains of Tindall et al. (2010). All physiological and biochemical tests were performed at $28{ }^{\circ} \mathrm{C}$ unless otherwise mentioned. Cellular morphology was observed by light microscopy and transmission electron microscopy after $24 \mathrm{~h}$ of growth on R2A medium (Difco; in $1 \mathrm{l}$ distilled water, $0.5 \mathrm{~g}$ yeast extract, $0.5 \mathrm{~g}$ proteose peptone, $0.5 \mathrm{~g}$ Casamino acids, $0.5 \mathrm{~g}$ glucose, $0.5 \mathrm{~g}$ soluble starch, $0.3 \mathrm{~g}$ sodium pyruvate, $0.3 \mathrm{~g}$ dipotassium phosphate, $0.05 \mathrm{~g}$ magnesium sulfate). For transmission electron microscopy, cells were negatively stained with $1 \%(\mathrm{w} / \mathrm{v})$ phosphotungstic acid. The motility of bacterial cells was observed on R2A swarming agar $(0.3 \%$, w/v). Oxidase activity was measured using the API $20 \mathrm{NE}$ test kit (bioMérieux) according to the manufacturer's instructions. Catalase activity was tested using young cells mixed with $3 \%(\mathrm{v} / \mathrm{v}) \mathrm{H}_{2} \mathrm{O}_{2}$ and monitoring for the production of oxygen bubbles (Gallego et al., 2006). Gram-staining was performed as described by Gerhardt et al. (1994) combined with the KOH lysis method (Ryu, 1938). Methyl red and Voges-Proskauer tests and $\mathrm{H}_{2} \mathrm{~S}$ production were analysed as described by Smibert \& Krieg (1994). Hydrolysis of casein, aesculin, gelatin, urea, starch, Tween 80, DNA, L-tyrosine, chitin from crab shells and CMcellulose was examined as described by Cowan \& Steel (1965). Enzyme activities, other biochemical characteristics and utilization of carbohydrates were determined using API ZYM, API 20 NE and API ID 32 GN kits, respectively, according to the manufacturer's instructions (bioMérieux). API ZYM test strips were read after $5 \mathrm{~h}$ of incubation at $37{ }^{\circ} \mathrm{C}$. The API $20 \mathrm{NE}$ and API ID $32 \mathrm{GN}$ tests were examined after incubation at $28{ }^{\circ} \mathrm{C}$ for $48 \mathrm{~h}$ and $72 \mathrm{~h}$, respectively.

Growth at $4,20,28,32,37$ and $42^{\circ} \mathrm{C}, \mathrm{pH} 4-10$ and $0,1,2$, 3,4 and $5 \%(\mathrm{w} / \mathrm{v}) \mathrm{NaCl}$ was assessed after 7 days of incubation in R2A broth (Difco). For pH tests, the broth was buffered with citrate/phosphate $(\mathrm{pH} 4.0-4.5), 10 \mathrm{mM}$ MES (pH 5.0-6.0), $10 \mathrm{mM}$ PIPES (pH 6.5-7.0) or $10 \mathrm{mM}$ Tris/ $\mathrm{HCl}(7.5-10)$ and adjusted with $\mathrm{NaOH}$ or $\mathrm{HCl}$. Growth was monitored by measuring the $\mathrm{OD}_{600}$. Anaerobic growth was examined by incubation in an anaerobic chamber (Mitsubishi Gas Chemical Co, Inc.) at $28{ }^{\circ} \mathrm{C}$ for 7 days on R2A agar. Antibiotic susceptibility tests were performed by spreading bacterial suspensions on culture plates and applying filter-paper discs containing different antibiotics according to the manufacturer's recommendation (Hangzhou Microbial Reagent Co., Ltd). Susceptibility was scored for inhibition zone diameters above $10 \mathrm{~mm}$. All tests were repeated at least twice. The minimium inhibitory concentration (MIC), defined as the lowest metal(loid) concentration that completely inhibited growth, was determined for $\mathrm{TS}^{\mathrm{T}}$ as described by Lim \& Cooksey (1993). Triplicate samples from single bacterial colonies were grown overnight at $28{ }^{\circ} \mathrm{C}$ with shaking at 160 r.p.m. Next, $2 \%$ original culture was inoculated into $5 \mathrm{ml}$ aliquots of R2A broth, each supplemented with serial concentrations of $\mathrm{NaAsO}_{2}$, $\mathrm{CuSO}_{4} \cdot 5 \mathrm{H}_{2} \mathrm{O}, \quad \mathrm{K}_{2}\left(\mathrm{C}_{4} \mathrm{H}_{2} \mathrm{O}_{6} \mathrm{Sb}\right)_{2} \cdot 3 \mathrm{H}_{2} \mathrm{O}, \quad \mathrm{ZnSO}_{4} \cdot 7 \mathrm{H}_{2} \mathrm{O}$, $\mathrm{NiSO}_{4} \cdot 6 \mathrm{H}_{2} \mathrm{O}$ and $3 \mathrm{CdSO}_{4} \cdot 8 \mathrm{H}_{2} \mathrm{O}$, to examine susceptibility to $\mathrm{As}^{3+}, \mathrm{Cu}^{2+}, \mathrm{Sb}^{3+}, \mathrm{Zn}^{2+}, \mathrm{Ni}^{2+}$ and $\mathrm{Cd}^{2+}$, respectively. Growth was measured as $\mathrm{OD}_{600}$ after incubation at $28{ }^{\circ} \mathrm{C}$ with shaking at 160 r.p.m. for 7 days.

Genomic DNA extraction was carried out as described previously (Cashion et al., 1977). The nearly complete $16 \mathrm{~S}$ rRNA gene sequence was amplified by PCR using primers Uni-27F and Uni-1492R (Wilson et al., 1990). The purified PCR product was ligated into the pGEM-T Easy vector (Promega). DNA sequencing was performed by the Beijing Genomics Institute (Beijing, China). The 16S rRNA gene sequence was compared with available sequences in the NCBI GenBank database and EzTaxon server 2.1. Gene sequences were aligned with those of related species using CLUSTAL_X software (Thompson et al., 1997). Phylogenetic analysis was performed using MEGA version 4.0 (Tamura et al., 2007) and PhyML software (Guindon \& Gascuel, 2003). Distance options according to the Kimura-2 model (Kimura, 1980) were determined and clustering was performed using the neighbour-joining (Saitou \& Nei, 1987), maximumparsimony (Kluge \& Farris, 1969) and maximum-likelihood (Felsenstein, 1981) algorithms. The robustness of the tree topologies was evaluated by calculating bootstrap values using 1000 resamplings (Felsenstein, 1985).

For cellular fatty acid analysis, strain $\mathrm{TS}^{\mathrm{T}}$ and four type strains with high $16 \mathrm{~S}$ rRNA gene sequence similarity $(M$. niastensis KACC $12599^{\mathrm{T}}$, M. consociata CCUG $58010^{\mathrm{T}}, M$. aerilata KACC $12505^{\mathrm{T}}$ and M. varians CCUG $35299^{\mathrm{T}}$ ) were grown at $28{ }^{\circ} \mathrm{C}$ for $48 \mathrm{~h}$ on R2A agar until exponential phase (Weon et al., 2009) and the fatty acids were analysed by GC (Hewlett Packard 6890) according to the instructions of the Sherlock Microbial Identification System [MIDI, Sherlock version 4.5 (0209B), TSBA40 4.10] (Sasser, 1990). Respiratory quinone analysis was performed by HPLC as described by Minnikin et al. (1984). Polar lipid analysis of strain $\mathrm{TS}^{\mathrm{T}}$ and type strains $M$. niastensis KACC $12599^{\mathrm{T}}$ and $M$. aerilata KACC $12505^{\mathrm{T}}$ was conducted under the same experimental conditions by two-dimensional TLC as described by Minnikin et al. (1984). The DNA G $+\mathrm{C}$ content was determined by HPLC according to the method of Mesbah et al. (1989). DNA-DNA hybridization analysis between strain $\mathrm{TS}^{\mathrm{T}}$ and each of the four type strains $M$. niastensis KACC $12599^{\mathrm{T}}$, M. consociata CCUG $58010^{\mathrm{T}}$, M. aerilata KACC $12505^{\mathrm{T}}$ and M. varians CCUG $35299^{\mathrm{T}}$ was performed by the thermal denaturation and renaturation method (Huß et al., 1983).

The detailed results of morphological, physiological and biochemical characterization of strain $\mathrm{TS}^{\mathrm{T}}$ are given in the species description. Strain $\mathrm{TS}^{\mathrm{T}}$ shared some properties 
Table 1. Differential characteristics of strain $\mathrm{TS}^{\top}{ }^{\top}$ and type strains of other species of the genus Massilia

Data in columns 1-6 are from this study unless indicated and were obtained after growth under the same conditions; data in parentheses were taken from Weon et al. (2009). Strains: 1 , TS3 ${ }^{\mathrm{T}}$; 2, M. niastensis KACC $12599^{\mathrm{T}}$; 3, M. consociata CCUG $58010^{\mathrm{T}}$; 4, M. aerilata KACC $12505^{\mathrm{T}}$; 5 , $M$. varians CCUG $35299^{\mathrm{T}}$; 6, M. haematophila CCUG $38318^{\mathrm{T}}$; 7, M. suwoensis $5414 \mathrm{~S}-25^{\mathrm{T}}$ (unless indicated, data from Weon et al., 2010); 8, M. albidiflava DSM $17472^{\mathrm{T}}$; 9, M. timonae DSM $16850^{\mathrm{T}}$; 10, M. lutea DSM $17473^{\mathrm{T}}$ (unless indicated, data in columns 8-10 from Weon et al., 2008); 11, M. niabensis KACC $12632^{\mathrm{T}}$ (Weon et al., 2009); 12, M. aurea DSM $18055^{\mathrm{T}}$ (Weon et al., 2008); 13, M. jejuensis 5317J-18 ${ }^{\mathrm{T}}$ (Weon et al., 2010); 14, M. brevitalea DSM $18925^{\mathrm{T}}$ (Zul et al., 2008; Weon et al., 2009); 15, M. dura DSM $17513^{\mathrm{T}}$ (Weon et al., 2008); 16, N. alkalitolerans KACC $12188^{\mathrm{T}}$ (Weon et al., 2010); 17, M. plicata DSM $17505^{\mathrm{T}}$ (Weon et al., 2008); 18, M. oculi CCUG 43427A ${ }^{\mathrm{T}}$ (Kämpfer et al., 2012). M. niastensis KACC 12599 ${ }^{\mathrm{T}}$ and M. aerilata KACC $12505^{\mathrm{T}}$ are the deposited strains in KACC corresponding to M. niastensis $5516 \mathrm{~S}-1^{\mathrm{T}}$ and M. aerilata $5516 \mathrm{~S}-11^{\mathrm{T}}$, respectively. + , Positive; w, weakly positive; -, negative; ND, no data available.

\begin{tabular}{|c|c|c|c|c|c|c|c|c|c|c|c|c|c|c|c|c|c|c|}
\hline Characteristic & 1 & 2 & 3 & 4 & 5 & 6 & 7 & 8 & 9 & 10 & 11 & 12 & 13 & 14 & 15 & 16 & 17 & 18 \\
\hline Nitrate reduction & + & - & - & + & - & - & - & + & - & - & + & - & - & + & - & $-{ }^{a \star}$ & - & - \\
\hline Urease & - & - & - & + & - & - & - & - & - & - & - & - & - & $-{ }^{b}$ & - & $++^{a}$ & - & - \\
\hline \multicolumn{19}{|l|}{ Hydrolysis of: } \\
\hline Aesculin & + & + & $\begin{array}{c}- \\
(+)\end{array}$ & + & $\mathrm{W}$ & - & - & + & + & + & - & + & + & $+{ }^{b}$ & + & $+{ }^{a}$ & + & + \\
\hline Starch & + & $\mathrm{W}$ & + & - & + & + & - & $+{ }^{c}$ & + & $+{ }^{c}$ & + & $+{ }^{c}$ & $\mathrm{w}$ & + & $-{ }^{c}$ & $-^{a}$ & $+{ }^{c}$ & ND \\
\hline Casein & + & - & + & + & + & + & + & $+{ }^{c}$ & $\mathrm{ND}$ & $+{ }^{c}$ & - & $+{ }^{c}$ & - & + & $+{ }^{c}$ & $\mathrm{ND}$ & $+{ }^{c}$ & ND \\
\hline Gelatin & + & + & + & + & $\mathrm{W}$ & $\mathrm{W}$ & + & + & + & + & - & + & - & - & + & $-{ }^{a}$ & + & ND \\
\hline \multicolumn{19}{|l|}{ Assimilation of: } \\
\hline D-Glucose & + & + & + & + & $\begin{array}{l}+ \\
(-)\end{array}$ & - & W & + & + & - & - & + & - & $+^{b}$ & + & + & + & + \\
\hline L-Rhamnose & - & + & - & - & + & - & - & + & + & - & - & + & - & - & + & + & + & + \\
\hline Lactic acid & + & - & - & - & - & - & + & + & + & - & - & - & - & - & - & - & - & - \\
\hline Glycogen & + & - & + & + & + & + & + & + & + & - & - & + & + & - & + & - & + & ND \\
\hline $\begin{array}{l}\text { 3-Hydroxybenzoic } \\
\text { acid }\end{array}$ & - & + & - & - & - & + & - & - & - & - & - & - & - & - & - & + & - & - \\
\hline Valeric acid & + & - & + & - & - & + & + & - & - & - & - & - & - & + & - & - & - & ND \\
\hline L-Histidine & + & - & - & + & $\begin{array}{c}+ \\
(-)\end{array}$ & - & + & - & + & - & - & - & - & - & - & + & - & - \\
\hline Potassium gluconate & + & + & - & - & - & - & - & + & + & + & - & - & - & $-{ }^{b}$ & + & - & + & - \\
\hline Malic acid & - & $\begin{array}{c}- \\
(+)\end{array}$ & + & + & + & + & + & - & + & - & - & + & - & $+^{b}$ & + & ND & + & $\mathrm{ND}$ \\
\hline $\mathrm{N}$-Acetylglucosamine & - & $\begin{array}{c}- \\
(+)\end{array}$ & - & - & - & - & - & + & - & + & - & + & - & $-^{b}$ & - & ND & - & $\mathrm{ND}$ \\
\hline Phenylacetic acid & - & - & - & + & - & + & + & - & + & - & - & - & - & $-{ }^{b}$ & - & ND & - & ND \\
\hline \multicolumn{19}{|l|}{ Enzyme activities } \\
\hline$\beta$-Galactosidase & - & + & - & - & + & - & - & + & + & + & + & + & - & - & + & + & - & $\mathrm{ND}$ \\
\hline$\alpha$-Galactosidase & - & - & - & - & - & - & - & + & - & - & - & - & - & - & + & + & + & ND \\
\hline$\alpha$-Glucosidase & + & - & - & + & + & + & + & - & - & - & + & $\mathrm{w}$ & + & + & - & + & - & ND \\
\hline$\beta$-Glucosidase & + & $\begin{array}{c}+ \\
(-)\end{array}$ & - & - & + & - & - & + & $\mathrm{W}$ & - & - & - & - & - & - & + & - & ND \\
\hline$\beta$-Glucuronidase & - & - & $\mathrm{W}$ & - & - & $-{ }^{d}$ & - & - & - & - & + & - & - & - & - & ND & - & ND \\
\hline Cystine arylamidase & - & + & - & + & + & $-{ }^{d}$ & $\mathrm{~W}$ & - & + & - & - & - & - & $-{ }^{b}$ & - & ND & - & ND \\
\hline $\begin{array}{l}\text { DNA G + C content } \\
(\mathrm{mol} \%)\end{array}$ & 65.9 & 66.6 & ND & 68.9 & ND & $\mathrm{ND}$ & 67.8 & $65.3^{e}$ & $62-67^{f}$ & $63.3^{e}$ & 67.8 & $66.0^{g}$ & 66.1 & 65.3 & $65.9^{e}$ & $62.4 \pm 0.3^{a}$ & $65.1^{e}$ & ND \\
\hline
\end{tabular}

${ }^{\star}$ Data taken from: $a$, Xu et al. (2005); b, Weon et al. (2009); c, Zul et al. (2008); d, Kämpfer et al. (2008); e, Zhang et al. (2006); $f$, Lindquist et al. (2003); g, Gallego et al. (2006).

with the type species, M. timonae, and other Massilia species, but also showed some differences (Table 1). The strain could be distinguished from related type strains in colony morphology, hydrolysis of casein, starch and Ltyrosine, reduction of nitrate and utilization of $\mathrm{L}$ rhamnose, lactic acid, glycogen, 3-hydroxybenzoic acid, valeric acid, L-histidine, malic acid and potassium gluconate as carbon sources. In contrast to other Massilia species, colonies of strain $\mathrm{TS}^{\mathrm{T}}$ were rough on R2A agar, and they were difficult to scrape. The MICs of strain TS $3^{\mathrm{T}}$ for $\mathrm{As}^{3+}, \mathrm{Cu}^{2+}, \mathrm{Zn}^{2+}, \mathrm{Ni}^{2+}, \mathrm{Sb}^{3+}$ and $\mathrm{Cd}^{2+}$ were 4.0, 4.0, 0.8, 0.6, 0.4 and $0.2 \mathrm{mM}$, respectively. Among these 
metal(loid)s, the MIC for $\mathrm{Cu}^{2+}$ was much higher than those of four closely related type strains $(4.0 \mathrm{mM}$, compared with $0.5 \mathrm{mM}$ for $M$. niastensis KACC $12599^{\mathrm{T}}$, M. aerilata KACC $12505^{\mathrm{T}}$ and M. varians CCUG $35299^{\mathrm{T}}$ and $0.3 \mathrm{mM}$ for M. consociata CCUG $58010^{\mathrm{T}}$ ).

The 1452 bp 16S rRNA gene sequence of strain $\mathrm{TS}^{\mathrm{T}}$ was analysed to determine its phylogenetic position. Strain $\mathrm{TS}^{\mathrm{T}}$ shared sequence similarities in the range 95.1-98.5\% with the type strains of the other 18 species of the genus Massilia. The most closely related type strains were $M$. niastensis $5516 \mathrm{~S}-1^{\mathrm{T}}$ (98.5\%), M. consociata CCUG $58010^{\mathrm{T}}$ $(97.6 \%)$, M. aerilata $5516 \mathrm{~S}-11^{\mathrm{T}}(97.4 \%)$ and M. varians CCUG $35299^{\mathrm{T}}(97.2 \%)$. A neighbour-joining tree based on $16 \mathrm{~S}$ rRNA gene sequences revealed that strain $\mathrm{TS}^{\mathrm{T}}$ formed a small phyletic lineage within the genus Massilia containing $M$. niastensis $5516 \mathrm{~S}-1^{\mathrm{T}}, M$. aerilata $5516 \mathrm{~S}-11^{\mathrm{T}}$ and $M$. consociata CCUG $58010^{\mathrm{T}}$ (Fig. 1). Strain $\mathrm{TS}^{\mathrm{T}}$ showed $96.5 \% 16 \mathrm{~S}$ rRNA gene sequence identity to the type strain of the type species, M. timonae, and was grouped into a large cluster containing M. timonae and the other 17 Massilia species. The maximum-parsimony and maximum-likelihood trees (Fig. S1, available in IJSEM Online) supported the phylogeny obtained with the neighbour-joining analysis. In all three phylogenetic trees, the two Telluria species were grouped together with the Massilia species (Fig. 1); however, strain $\mathrm{TS}^{\mathrm{T}}$ shared lower $16 \mathrm{~S}$ rRNA gene sequence similarities with the type strains of the two Telluria species ( 94 and $93 \%$, for Telluria chitinolytica and T. mixta, respectively). Kämpfer et al. (2011) suggested that the Telluria species may need to be carefully re-investigated. It is also interesting to note that Duganella violaceinigra YIM $31327^{\mathrm{T}}$ was clustered with the Massilia species using the neighbour-joining and maximum-likelihood methods (Figs 1 and S1b), but it was grouped in another cluster containing Duganella zoogloeoides IAM $12670^{\mathrm{T}}$ in the maximum-parsimony tree (Fig. S1a). However, D. violaceinigra YIM $31327^{\mathrm{T}}$ showed only $95.9 \% 16 \mathrm{~S}$ rRNA gene sequence identity to strain $\mathrm{TS}^{\mathrm{T}}$ and had different major fatty acids $\left(\mathrm{C}_{16: 0}\right.$ and $\left.\mathrm{C}_{12: 0}\right)$ compared with Massilia species.

Similar to the type species $M$. timonae and other members of the genus Massilia, strain TS3 ${ }^{\mathrm{T}}$ contained ubiquinone Q$8(91.2 \%)$ as the major respiratory quinone. The DNA $\mathrm{G}+\mathrm{C}$ content of strain $\mathrm{TS}^{\mathrm{T}}$ was $65.9 \mathrm{~mol} \%$, which was within the $\mathrm{G}+\mathrm{C}$ content range reported for Massilia. The major fatty acids were summed feature $3\left(\mathrm{C}_{16: 1} \omega 7 c\right.$ and/or iso- $\left.\mathrm{C}_{15: 0} \quad 2-\mathrm{OH} ; \quad 40.3 \%\right), \quad \mathrm{C}_{16: 0} \quad(21.1 \%), \quad \mathrm{C}_{18: 1} \omega 7 c$ $(15.2 \%), \mathrm{C}_{12: 0}(6.5 \%), \mathrm{C}_{10: 0} 3-\mathrm{OH}(6.3 \%)$ and $\mathrm{C}_{12: 0} 2-$ $\mathrm{OH}(5.3 \%)$, in agreement with the characteristics of Massilia (Table 2). The major polar lipids of strain $\mathrm{TS}^{\mathrm{T}}$ were phosphatidylethanolamine, phosphatidylglycerol and diphosphatidylglycerol (Fig. S2), identical to the major polar lipids reported for M. flava $\mathrm{Y9}^{\mathrm{T}}$ (Wang et al., 2012), M. consociata CCUG 58010 ${ }^{\mathrm{T}}$ (Kämpfer et al., 2011), M. oculi CCUG 43427A ${ }^{\mathrm{T}}$ (Kämpfer et al., 2012), M. jejuensis KACC $12634^{\mathrm{T}}$, M. suwonensis KACC $12635^{\mathrm{T}}$, M. brevitalea DSM $18925^{\mathrm{T}}$, M. alkalitolerans KACC $12188^{\mathrm{T}}$ (Weon et al., 2010), M. varians CCUG $35299^{\mathrm{T}}$ and M. haematophila CCUG $38318^{\mathrm{T}}$ (Kämpfer et al., 2008). In addition, strain $\mathrm{TS}^{\mathrm{T}}$ also had a small amount of an unknown lipid (Fig. S2). M. niastensis KACC $12599^{\mathrm{T}}$ and M. aerilata KACC $12505^{\mathrm{T}}$, closely related type strains for which no polar lipid data were available, were analysed in parallel in this study and showed the same major polar lipids as strain $\mathrm{TS}^{\mathrm{T}}$ (Fig. S2). In DNA-DNA hybridization tests, the relatedness between strain $\mathrm{TS}^{\mathrm{T}}$ and M. niastensis KACC $12599^{\mathrm{T}}, M$.

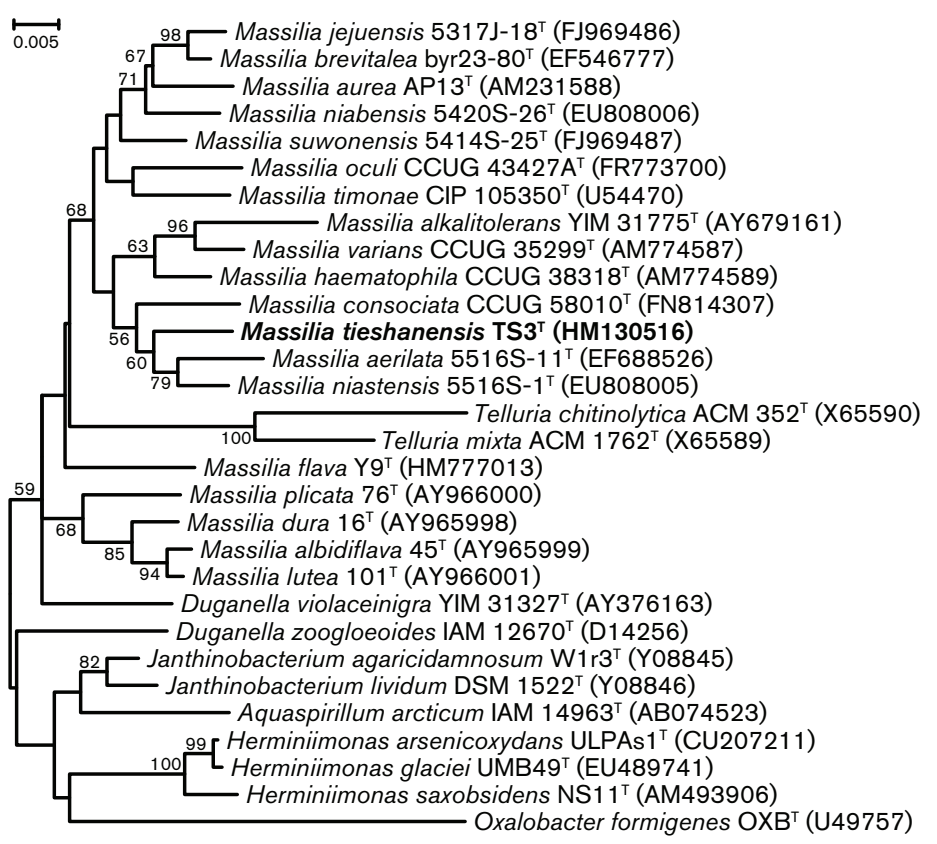

Fig. 1. Neighbour-joining phylogenetic tree based on 16S rRNA gene sequences. The position of strain $\mathrm{TS}^{\mathrm{T}}$ is shown with respect to other closely related species. Numbers at nodes indicate bootstrap values, expressed as percentages of 1000 replications; values $>50 \%$ are shown. Bar, 0.005 accumulated changes per nucleotide. 
Table 2. Cellular fatty acid compositions of strain $\mathrm{TS}^{\top}$ and the type strains of Massilia species

Strains: 1 , TS3 ${ }^{\mathrm{T}}$; 2, M. niastensis KACC $12599^{\mathrm{T}}$; 3, M. consociata CCUG $58010^{\mathrm{T}}$; 4, M. aerilata KACC $12505^{\mathrm{T}}$; 5, M. varians CCUG $35299^{\mathrm{T}}$; 6 , M. haematophila CCUG $38318^{\mathrm{T}}$ (data from Weon et al., 2010); 7, M. suwoensis 5414S-25 ${ }^{\mathrm{T}}$ (Weon et al., 2010); 8, M. albidiflava DSM 17472 ${ }^{\mathrm{T}}$; 9, M. timonae DSM $16850^{\mathrm{T}}$; 10, M. lutea DSM $17473^{\mathrm{T}}$ (data in columns 8-10 from Weon et al., 2008); 11, M. niabensis KACC $12632^{\mathrm{T}}$ (Weon et al., 2009); 12, M. aurea DSM $18055^{\mathrm{T}}$ (Gallego et al., 2006); 13, M. jejuensis 5317J-18 ${ }^{\mathrm{T}}$ (Weon et al., 2010); 14, M. brevitalea DSM 18925 ${ }^{\mathrm{T}}$ (Weon et al., 2009); 15, M. dura DSM $17513^{\mathrm{T}}$ (Weon et al., 2008); 16, M. alkalitolerans KACC $12188^{\mathrm{T}}$ (Weon et al., 2010); 17, M. plicata DSM $17505^{\mathrm{T}}$ (Zhang et al., 2006); 18, M. oculi CCUG $43427 \mathrm{~A}^{\mathrm{T}}$ (Kämpfer et al., 2012). Data in columns 1-5 are from this study. Values are percentages of total fatty acids; $<1 \%$ or not detected.

\begin{tabular}{|c|c|c|c|c|c|c|c|c|c|c|c|c|c|c|c|c|c|c|}
\hline Fatty acid & 1 & 2 & 3 & 4 & 5 & 6 & 7 & 8 & 9 & 10 & 11 & 12 & 13 & 14 & 15 & 16 & 17 & 18 \\
\hline $\mathrm{C}_{12: 0}$ & 6.5 & 7.8 & 6.3 & 5.4 & 5.2 & 3.3 & 4.4 & 5.3 & 3.3 & 4.0 & 8.9 & 4.4 & 5.9 & 5.0 & 3.9 & 3.3 & 7.1 & 7.7 \\
\hline $\mathrm{C}_{14: 0}$ & - & 1.0 & - & 3.4 & - & - & 1.2 & 2.6 & - & 1.2 & - & 2.0 & - & - & 1.1 & - & - & 1.0 \\
\hline $\mathrm{C}_{14: 0} 2-\mathrm{OH}$ & - & - & - & 2.6 & - & - & - & 2.4 & - & 2.9 & - & 2.5 & - & - & 2.6 & - & 6.1 & - \\
\hline$C_{16: 0}$ & 21.1 & 22.9 & 14.2 & 26.1 & 21.7 & 26.2 & 28.8 & 23.4 & 30.5 & 26.6 & 23.6 & 27.2 & 22.5 & 23.0 & 27.5 & 26.6 & 25.1 & 20.9 \\
\hline $\mathrm{C}_{17: 0}$ cyclo & 1.8 & 3.3 & - & 9.5 & 6.3 & 2.7 & 2.9 & - & 3.7 & - & - & - & 1.0 & - & - & - & - & 1.0 \\
\hline iso- $\mathrm{C}_{17: 0}$ & - & - & - & - & - & 1.6 & - & - & - & - & - & - & - & - & - & - & - & - \\
\hline iso- $\mathrm{C}_{17: 1} \omega 9 c$ & - & - & - & - & - & 1.4 & - & - & - & - & - & - & - & - & - & - & - & - \\
\hline $\mathrm{C}_{18: 1} \omega 7 c$ & 15.2 & 7.0 & 11.2 & 5.4 & 6.5 & 8.7 & 7.8 & 7.4 & 7.9 & 7.8 & 7.8 & 7.9 & 12.1 & 9.0 & 7.0 & 6.6 & 11.7 & 6.0 \\
\hline $\mathrm{C}_{18: 0}$ & 1.0 & - & - & - & - & - & - & - & - & - & - & - & - & - & - & - & - & - \\
\hline $\mathrm{C}_{20: 0}$ & - & - & - & - & - & - & - & - & - & - & - & - & - & - & - & - & - & - \\
\hline
\end{tabular}

${ }^{*}$ Summed feature 3 included $\mathrm{C}_{16: 1} \omega 7 c$ and/or iso- $\mathrm{C}_{15: 0} 2-\mathrm{OH}$.

consociata CCUG $58010^{\mathrm{T}}$, M. aerilata KACC $12505^{\mathrm{T}}$ and M. varians CCUG $35299^{\mathrm{T}}$ was $36.5 \pm 0.6,27.1 \pm 2.6$, $22.7 \pm 1.3$ and $46.5 \pm 1.2 \%$, respectively. These DNADNA relatedness values were considerably less than $70 \%$, indicating that strain $\mathrm{TS}^{\mathrm{T}}$ represents a novel species distinct from the four tested reference strains (Wayne et al., 1987).

In summary, the $16 \mathrm{~S}$ rRNA gene sequence similarity, major fatty acids, the presence of Q-8 as the major respiratory quinone, the polar lipids and the DNA G $+\mathrm{C}$ content showed that strain $\mathrm{TS}^{\mathrm{T}}$ belonged to the genus Massilia. However, strain $\mathrm{TS}^{\mathrm{T}}$ showed clear differences in morphological, physiological/biochemical features and low DNADNA hybridization with the type strains of related species. On the basis of the phenotypic and phylogenetic characteristics, strain $\mathrm{TS}^{\mathrm{T}}$ should be classified within a novel species of the genus Massilia, for which the name Massilia tieshanensis sp. nov. is proposed.

\section{Description of Massilia tieshanensis sp. nov.}

Massilia tieshanensis (tie.sha.nen'sis. N.L. fem. adj. tieshanensis of or belonging to Tieshan, referring to the isolation of the type strain from mine soil in Tieshan, China).

Cells are Gram-negative, non-spore-forming, rod-shaped $(0.3-0.6 \times 1.2-2.0 \mu \mathrm{m})$ and motile with flagella (Fig. S3). Colonies are circular, convex, viscous, translucent, strawyellow, $1.0-2.0 \mathrm{~mm}$ in diameter with entire edges on nutrient agar plates after $36 \mathrm{~h}$ of incubation. Some differences are observed using R2A medium, on which colonies are opaque, yellowish and rough. Grows on nutrient agar, R2A and trypticase soy agar, but does not grow on MacConkey agar. Cannot grow under anaerobic conditions. Aerobic growth can be observed at $10-40{ }^{\circ} \mathrm{C}$, with optimum growth at $28{ }^{\circ} \mathrm{C}$. The $\mathrm{pH}$ range for growth is 5.0-9.0, with optimum growth at $\mathrm{pH}$ 7.0. Growth does not require $\mathrm{NaCl}$, but the type strain can tolerate $1 \%(\mathrm{w} / \mathrm{v})$ $\mathrm{NaCl}$. Oxidase- and catalase-positive. $\mathrm{H}_{2} \mathrm{~S}$ is not produced. Methyl red and Voges-Proskauer tests are negative. Hydrolyses casein and starch, but not L-tyrosine, CMcellulose, chitin, DNA or Tween 80. Positive for nitrate reduction and hydrolysis of aesculin and gelatin, but negative for $\beta$-galactosidase, indole production, glucose fermentation, urease and arginine dihydrolase (API $20 \mathrm{NE}$ test strip). Assimilates D-glucose, L-arabinose, D-mannose, potassium gluconate, lactic acid, sodium acetate, glycogen, valeric acid, sucrose, maltose, L-histidine, 3-hydroxybutyric acid and L-proline, but not L-rhamnose, D-ribose, L-fucose, D-mannitol, inositol, salicin, melibiose, D-sorbitol, Lalanine, L-serine, $\mathrm{N}$-acetylglucosamine, adipic acid, malic acid, capric acid, trisodium citrate, propionic acid, itaconic acid, phenylacetic acid, sodium malonate, potassium 5ketogluconate, 3-hydroxybenzoic acid, potassium 2-ketogluconate or 4-hydroxybenzoic acid (API $20 \mathrm{NE}$ and API ID $32 \mathrm{GN}$ test strips). Also assimilates D-fructose, trehalose, lactose, D-galactose, cellobiose, raffinose, tartrate, pyruvate, $\beta$-hydroxybutyrate, L-arginine, creatine and L-threonine, 
but not succinate, glycerol, malate, L-cysteine, L-leucine or L-tryptophan. Positive for alkaline phosphatase, esterase (C4), esterase lipase (C8), leucine arylamidase, valine arylamidase, $\alpha$-glucosidase, $\beta$-glucosidase, acid phosphatase and naphthol-AS-BI-phosphohydrolase, but negative for lipase (C14), cystine arylamidase, trypsin, $\alpha$-chymotrypsin, $\alpha$-galactosidase, $\beta$-galactosidase, $\beta$-glucuronidase, $N$-acetyl- $\beta$-glucosaminidase, $\alpha$-mannosidase and $\alpha$-fucosidase (API ZYM test strip). Sensitive to amoxicillin $(20 \mu \mathrm{g})$, ampicillin $(10 \mu \mathrm{g})$, cefotaxime $(30 \mu \mathrm{g})$, cefoxitin $(30 \mu \mathrm{g})$, chloramphenicol $(30 \mu \mathrm{g})$, erythromycin $(15 \mu \mathrm{g})$, kanamycin $(30 \mu \mathrm{g})$, nalidixic acid $(30 \mu \mathrm{g})$, neomycin $(30 \mu \mathrm{g})$, nitrofurantoin $(30 \mu \mathrm{g})$, novobiocin $(30 \mu \mathrm{g})$, polymyxin B $(25 \mu \mathrm{g})$, streptomycin $(10 \mu \mathrm{g})$, penicillin $(10 \mu \mathrm{g})$, tobramycin $(10 \mu \mathrm{g})$ and trimethoprim $(5 \mu \mathrm{g})$. The major fatty acids $(>10 \%)$ are summed feature $3\left(\mathrm{C}_{16: 1} \omega 7 c\right.$ and/or iso$\left.\mathrm{C}_{15: 0} 2-\mathrm{OH}\right), \mathrm{C}_{16: 0}$ and $\mathrm{C}_{18: 1} \omega 7 c$. The predominant respiratory quinone is ubiquinone Q-8. The major polar lipids are phosphatidylethanolamine, phosphatidylglycerol and diphosphatidylglycerol. The DNA G $+\mathrm{C}$ content of the type strain is $65.9 \mathrm{~mol} \%$.

The type strain, $\mathrm{TS}^{\mathrm{T}}{ }^{\mathrm{N}}=\mathrm{CCTCC} \mathrm{AB} 2010202^{\mathrm{T}}=\mathrm{KACC}$ $14940^{\mathrm{T}}$ ), was isolated from subsurface soil of a metal mine at Tieshan, Hubei Province, central China.

\section{Acknowledgements}

We are grateful to KACC and CCUG for providing type strains, Dr Chengxiang Fang (CCTCC) for respiratory quinone analysis, Dr Wenjun Li (Yunnan University) for polar lipid analysis, Dr Jean Euzéby (École National Vétérinaire, Toulouse) for advice on the etymology of the name of the novel species and Dr Christopher Rensing (University of Arizona) for editing. This work was supported by a Major International Joint Research Project of Chinese National Natural Science Foundation (\#31010103903).

\section{References}

Cai, L., Liu, G., Rensing, C. \& Wang, G. (2009). Genes involved in arsenic transformation and resistance associated with different levels of arsenic-contaminated soils. BMC Microbiol 9, 4.

Cashion, P., Holder-Franklin, M. A., McCully, J. \& Franklin, M. (1977). A rapid method for the base ratio determination of bacterial DNA. Anal Biochem 81, 461-466.

Cowan, S. T. \& Steel, K. J. (1965). Manual for the Identification of Medical Bacteria. London: Cambridge University Press.

Felsenstein, J. (1981). Evolutionary trees from DNA sequences: a maximum likelihood approach. J Mol Evol 17, 368-376.

Felsenstein, J. (1985). Confidence limits on phylogenies: an approach using the bootstrap. Evolution 39, 783-791.

Gallego, V., Sánchez-Porro, C., García, M. T. \& Ventosa, A. (2006). Massilia aurea sp. nov., isolated from drinking water. Int J Syst Evol Microbiol 56, 2449-2453.

Gerhardt, P., Murray, R. G. E., Wood, W. A. \& Krieg, N. R. (editors) (1994). Methods for General and Molecular Bacteriology. Washington, DC: American Society for Microbiology.

Guindon, S. \& Gascuel, O. (2003). A simple, fast, and accurate algorithm to estimate large phylogenies by maximum likelihood. Syst Biol 52, 696-704.
Huß, V. A. R., Festl, H. \& Schleifer, K. H. (1983). Studies on the spectrophotometric determination of DNA hybridization from renaturation rates. Syst Appl Microbiol 4, 184-192.

Kämpfer, P., Falsen, E. \& Busse, H. J. (2008). Naxibacter varians sp. nov. and Naxibacter haematophilus sp. nov., and emended description of the genus Naxibacter. Int J Syst Evol Microbiol 58, 1680-1684.

Kämpfer, P., Lodders, N., Martin, K. \& Falsen, E. (2011). Revision of the genus Massilia La Scola et al. 2000, with an emended description of the genus and inclusion of all species of the genus Naxibacter as new combinations, and proposal of Massilia consociata sp. nov. Int J Syst Evol Microbiol 61, 1528-1533.

Kämpfer, P., Lodders, N., Martin, K. \& Falsen, E. (2012). Massilia oculi sp. nov., isolated from a human clinical specimen. Int J Syst Evol Microbiol 62, 364-369.

Kimura, M. (1980). A simple method for estimating evolutionary rates of base substitutions through comparative studies of nucleotide sequences. J Mol Evol 16, 111-120.

Kluge, A. G. \& Farris, J. S. (1969). Quantitative phyletics and the evolution of anurans. Syst Zool 18, 1-32.

La Scola, B., Birtles, R. J., Mallet, M. N. \& Raoult, D. (1998). Massilia timonae gen. nov., sp. nov., isolated from blood of an immunocompromised patient with cerebellar lesions. J Clin Microbiol 36, 28472852.

Lim, C. K. \& Cooksey, D. A. (1993). Characterization of chromosomal homologs of the plasmid-borne copper resistance operon of Pseudomonas syringae. J Bacteriol 175, 4492-4498.

Lindquist, D., Murrill, D., Burran, W. P., Winans, G., Janda, J. M. \& Probert, W. (2003). Characteristics of Massilia timonae and Massilia timonae-like isolates from human patients, with an emended description of the species. J Clin Microbiol 41, 192-196.

Mesbah, M., Premachandran, U. \& Whitman, W. B. (1989). Precise measurement of the $\mathrm{G}+\mathrm{C}$ content of deoxyribonucleic acid by highperformance liquid chromatography. Int J Syst Bacteriol 39, 159-167.

Minnikin, D. E., O'Donnell, A. G., Goodfellow, M., Alderson, G., Athalye, M., Schaal, A. \& Parlett, J. H. (1984). An integrated procedure for the extraction of bacterial isoprenoid quinones and polar lipids. J Microbiol Methods 2, 233-241.

Ryu, E. (1938). On the Gram-differentiation of bacteria by the simplest method. J Jpn Soc Vet Sci 17, 58-63.

Saitou, N. \& Nei, M. (1987). The neighbor-joining method: a new method for reconstructing phylogenetic trees. Mol Biol Evol 4, 406425.

Sasser, M. (1990). Identification of bacteria by gas chromatography of cellular fatty acids, MIDI Technical Note 101. Newark, DE: MIDI Inc.

Sintchenko, V., Jelfs, P., Sharma, A., Hicks, L., Gilbert, G. L. \& Waller, C. (2000). Massilia timonae: an unusual bacterium causing wound infection following surgery. Clin Microbiol Newsl 22, 149-151.

Smibert, R. M. \& Krieg, N. R. (1994). Phenotypic characterization. In Methods for General and Molecular Bacteriology, pp. 607-654. Edited by P. Gerhardt, R. G. E. Murray, W. A. Wood \& N. R. Krieg. Washington, DC: American Society for Microbiology.

Tamura, K., Dudley, J., Nei, M. \& Kumar, S. (2007). MEGA4: molecular evolutionary genetics analysis (MEGA) software version 4.0. Mol Biol Evol 24, 1596-1599.

Thompson, J. D., Gibson, T. J., Plewniak, F., Jeanmougin, F. \& Higgins, D. G. (1997). The CLUSTAL_X windows interface: flexible strategies for multiple sequence alignment aided by quality analysis tools. Nucleic Acids Res 25, 4876-4882.

Tindall, B. J., Rosselló-Móra, R., Busse, H.-J., Ludwig, W. \& Kämpfer, P. (2010). Notes on the characterization of prokaryote strains for taxonomic purposes. Int J Syst Evol Microbiol 60, 249-266. 
Wang, J. W., Zhang, J. L., Pang, H. C., Zhang, Y. B., Li, Y. Y. \& Fan, J. P. (2012). Massilia flava sp. nov., isolated from soil. Int J Syst Evol Microbiol 62, 580-585.

Wayne, L. G., Brenner, D. J., Colwell, R. R., Grimont, P. A. D., Kandler, O., Krichevsky, M. I., Moore, L. H., Moore, W. E. C., Murray, R. G. E. \& other authors (1987). International Committee on Systematic Bacteriology. Report of the ad hoc committee on reconciliation of approaches to bacterial systematics. Int J Syst Bacteriol 37, 463-464.

Weon, H. Y., Kim, B. Y., Son, J. A., Jang, H. B., Hong, S. K., Go, S. J. \& Kwon, S. W. (2008). Massilia aerilata sp. nov., isolated from an air sample. Int J Syst Evol Microbiol 58, 1422-1425.

Weon, H. Y., Kim, B. Y., Hong, S. B., Jeon, Y. A., Koo, B. S., Kwon, S. W. \& Stackebrandt, E. (2009). Massilia niabensis sp. nov. and Massilia niastensis sp. nov., isolated from air samples. Int J Syst Evol Microbiol 59, 1656-1660.

Weon, H. Y., Yoo, S. H., Kim, S. J., Kim, Y. S., Anandham, R. \& Kwon, S. W. (2010). Massilia jejuensis sp. nov. and Naxibacter suwonensis sp. nov., isolated from air samples. Int J Syst Evol Microbiol 60, 1938-1943.
Wilson, K. H., Blitchington, R. B. \& Greene, R. C. (1990). Amplification of bacterial $16 \mathrm{~S}$ ribosomal DNA with polymerase chain reaction. J Clin Microbiol 28, 1942-1946.

Xu, P., Li, W. J., Tang, S. K., Zhang, Y. Q., Chen, G.-Z., Chen, H.-H., Xu, L. H. \& Jiang, C. L. (2005). Naxibacter alkalitolerans gen. nov., sp. nov., a novel member of the family 'Oxalobacteraceae' isolated from China. Int J Syst Evol Microbiol 55, 1149-1153.

Zhang, X.-J., Hu, M.-A., Zhao, Y.-H. \& Zhao, B.-S. (2005). A survey of heavy metals pollution in Daye Tieshan Area. Environ Sci Technol (China) 28, 40-43.

Zhang, Y.-Q., Li, W.-J., Zhang, K.-Y., Tian, X.-P., Jiang, Y., Xu, L.-H., Jiang, C.-L. \& Lai, R. (2006). Massilia dura sp. nov., Massilia albidiflava sp. nov., Massilia plicata sp. nov. and Massilia lutea sp. nov., isolated from soils in China. Int J Syst Evol Microbiol 56, 459463.

Zul, D., Wanner, G. \& Overmann, J. (2008). Massilia brevitalea sp. nov., a novel betaproteobacterium isolated from lysimeter soil. Int $J$ Syst Evol Microbiol 58, 1245-1251. 